\begin{tabular}{|lr|}
\hline $\begin{array}{l}\text { Social Work/Maatskaplike Werk Vol } 51 \text { No 4; Issue } 3 \\
\text { http://socialwork.journals.ac.za/pub }\end{array}$ & doi:http://dx.doi.org/51-4-463 \\
\hline
\end{tabular}

TEACHING SOCIAL WORK VALUES BY MEANS OF SOCRATIC QUESTIONING

Sandra Ferreira, Regardt Ferreira ferreirs@ufs.ac.za

This article provides an outline of the challenging process of teaching, acquiring and internalising social work values, which form an important aspect on which ultimate ethical decision making with clients rests. The supposition is that treating clients impartially, reasonably and justly is dependent on students' understanding and awareness of their thinking about their thinking. Becoming a strong-sense thinker implies a cultivated disposition of mind without privileging one's own views and being skilled in the ability to formulate a disciplined line of questioning. The use of Socratic Questioning (SQ) as a form of professional socialisation to teaching professional values may enable students to eventually develop into reflective practitioners. 



\section{TEACHING SOCIAL WORK VALUES BY MEANS OF SOCRATIC QUESTIONING}

\section{Sandra Ferreira, Regardt Ferreira}

\section{INTRODUCTION}

There is an expectation that students will be taught and encouraged to use critical thinking during the course of their education and in their practice. However, according to Coleman, Rogers and King (2002), it seems that educators expect or believe that social work students will develop critical skills as a by-product of the educational experience. Social work education in South Africa is regulated primarily by policy documents of the South African Qualifications Authority (SAQA, 2009, 2010), earlier regulations for National Standards Bodies (Government Gazette No. 18787, 1998) and the Standards Generating Body (SGB) of the South African Council for Social Service Professions (SACSSP, 2004). These policy documents refer to, among other things, the importance of professional values, and critical thinking and reflection (Government Gazette No. 30353, 2007). Although exit-level outcomes in social work education do not specifically require that problems should be identified and solved by using critical and creative thinking (critical cross-field outcome one) in the case of exit-level outcomes 9 and 10, referring to values of social work and ethical principles, it is expected that "critical cross-field outcomes ... shall be embedded within a standard ...provided that where such standard forms part of a qualification, those critical cross-field outcomes not included in the standard shall be embedded in the qualification" (Government Gazette No 18787, 1998: Regulation 7(2)). Nevertheless, the BSW qualification gives a heavy weighting to the development of practitioners who are critically reflective and able to practise within the value perspective of the social work profession. The overarching values that guide social work education and training are social justice and respect for all (Bachelor of Social Work [BSW)] NQF Level 8) (SAQA, 2009). These values are embedded within a developmental social welfare services paradigm, thereby fostering a people-centred approach in both social work education and practice (Patel, Triegaardt \& Ndangwa, 2005; SAQA, 2009).

Consequently social work educators need to include critical thinking in their teaching strategies to facilitate a process whereby students reflect on their thinking in order to guide them to become well-cultivated deliberators as they address the wellbeing of people in their environments. Social work students come to professional education with their own personal beliefs and values and, as Perlman (1976) stated in the 1970s, "like every one of us ... social work student[s] [are] often quite unconscious of the values that silently and powerfully guide [their] internal and external behaviour". This sentiment is also echoed by Gray and Gibbons (2007:223) in the twenty-first century: "we need to teach students to reflect on the way in which their reasoning, actions and decisions are affected by their values". The rights of students to their personal and cultural beliefs should be respected, but they should be helped to reason critically about these in order to understand their influence on their ultimate ethical decision-making. 
While definitions of beliefs may differ semantically across disciplines, one common denominator, according to Saleebey (2009), is the claim that beliefs are constructed and inferred. Personal beliefs are statements, principles or doctrines that people believe to be true based on evaluation and judgement (Pajares, 1992). Values can be derived from a set of beliefs in which individuals have an emotional investment (Walsh, 2010) and which are deemed as important by the individual, for example, the belief that children are vulnerable, while the value of family life stems from this belief. According to Hepworth, Rooney, Rooney, Strom-Gottfried and Larsen (2002:8), "[v]alues represent strongly held beliefs about how the world should be, how people should normally behave, and about preferred conditions of life". The profession of social work strives to nurture and enhance the welfare and wellbeing of client systems. For social workers to accomplish this, they adhere to a Code of Ethics based on a set of professional values. These professional values have to be mastered during social work education and one way of accomplishing this in an intellectually disciplined way might be what Paul and Elder (2007a) refer to as the development of critical skill abilities by using Socratic Questioning (SQ). According to them, "all subjects of study are learned, understood and applied by thinking" (Paul \& Elder, 2012:146), thereby fostering "strong-sense critical thinkers" (Paul \& Elder, 2012:2). A striking characteristic of strong-sense critical thinkers is their consistent pursuit of the fair and just, and acting in the public good (Paul $\&$ Elder, 2012). The same professional action is required from the social worker, according to values explicated in national and international codes of ethics.

The aim of this article is to provide an outline of the challenging process of the acquisition and mastering of professional values during social work education, where critical thinking is an important point of departure in grasping these values. Helping students to realise the importance of critical thinking or thinking about thinking in learning, and eventually in ethical decision making, can be facilitated by the utilisation of Socratic Questioning (SQ), when teaching social work values within an indigenous context. SQ helps students to go beneath the surface and to establish a powerful voice of reason. The skill of critical thinking should be cultivated and nurtured consciously during the education of social work students. It is important, as the ability to formulate, analyse and assess is a trademark of fair-minded social work students and practitioners. This article provides a review of the values of social work and explains SQ as a method of critical thinking for teaching social work values. Furthermore, in this article the implications for teaching social work values in a South African context are discussed by means of SQ.

\section{THE VALUES OF SOCIAL WORK IN THE SOUTH AFRICAN CODE OF ETHICS}

Social workers have a professional responsibility and duty to understand ethics and values, because social work practice contains the potential for the misuse of power, among other things (Payne \& Littlechild, 2000). This misuse might have a negative impact on human wellbeing and the empowerment of people who are vulnerable, disadvantaged and impoverished - the same issues and situations the profession is sanctioned to address in terms of its values. Social work values can be defined as beliefs 
about what is desirable in the profession and in society or, more specifically, strongly held beliefs about the rights of people to free choice and opportunity (Hepworth et al., 2002). These value preferences form the basis for the profession concerning purpose, direction and action, while ethics refers to "aspects of philosophy concerned with the principles of right and wrong that guide conduct" (Shardlow, 2009:37).

Social work as a profession grew out of humanitarian and democratic ideals (IFSW, 2000) and is committed to focusing on social change, problem solving in human relationships and the liberation of people to enhance wellbeing (Payne, 2006). Core values have been identified throughout the history of social work as a profession and have been articulated in the codes of ethics of different countries. Although Pinkerton (2002:99) cautions that "values are not neat, safe, feel-good phrases, but challenging guides to action within particular circumstances", the values of social work continue to be recognised as an essential ingredient of sound ethical social work practice (Abbott, 2003).

In South Africa social work values, and ethical principles and standards are articulated in a Code of Ethics by the South African Council for Social Service Professions (SACSSP), guiding "social workers' conduct as well as providing guidance with ethical challenges" (SACSSP, 2004:4). This statutory body regulates the Social Service Professions in terms of the Social Service Professions Act 110 of 1978, as amended. According to Gray and Gibbons (2007), values are ideals, whereas ethics guides the individual towards the achievement of these ideals. Values are not fixed as they are based on beliefs and thus "the importance of asking deep questions that probe profoundly into thinking before we accept ideas as worthy of belief" should be recognised (Paul \& Elder, 2012:412). Nonetheless, the following primary social work values of social development practice form the ideals or cornerstone of the profession in South Africa. These values are derived from the South African Constitution, international instruments, and local and international codes of ethics (Patel, 2005) and should consequently also be subjected to deep questioning, as social work practice priorities change along with trends in the environment.

Social justice - although a contested and pluralistic concept with no "comprehensive, indisputable definition of the term" in social work literature, it has taken a prominent place in the code of ethics for social work (Bonnycastle, 2011:266). This state of affairs underscores the importance of teaching students to familiarise themselves by explicitly reflecting upon and locate their own personal understanding of social justice as a system that "moves society closer to the possibility of social equality" (Bonnycastle, 2011:291). Working towards the possibility of social equality may imply pursuing social change with, and on behalf of, vulnerable and disadvantaged populations by upholding and protecting rights, opportunities, obligations and social benefits for all citizens (Patel, 2005).

Respect for people's worth, human rights and dignity awareness, humanity (ubuntu) and sensitivity to diversity by respecting clients' privacy, confidentiality, self-determination and autonomy, and being mindful that legal and other obligations may lead to conflict and inconsistencies in exercising these rights (SACSSP, 2004). Apart from an individualistic viewpoint of respect for the individual, respect should also include a structural component. In this way respect for people must, according to Gray and 
Stofberg (2000:60), be "holistic" and should include "the caring exploration of the other, involvement with the interrelated networks of relationships which contextualise individuals" or "the value of interpersonal relationships" (Graham, 1999:258).

Competence should be demonstrated by having the necessary knowledge and skills to work effectively with people and to strive for high standards of competence (SACSSP, 2004). Competence implies that social workers are ethically bound to conduct themselves in a trustworthy and accountable manner, adhering to high moral ideals by promoting honesty in science, teaching and practising the profession with integrity, which means being aware of one's own belief system, values, needs and limitations, and the effect they have on one's work (SACSSP, 2004).

Professional responsibility - relates to competence and refers to accountability, transparency, confidentiality and efficiency in relation to client systems, but also to other groupings such as colleagues, professionals, the profession and society (SACSSP, 2004).

Show care and concern for others' wellbeing by recognising the importance of human relationships through not misleading or exploiting human beings during or after termination of the social work relationship (SACSSP, 2004).

Service delivery should take place by assisting clients by providing help and resources to address their social needs and problems in order for them to reach their full potential. Social workers therefore elevate service delivery to others above self-interest (Patel, 2005; SACSSP, 2004).

Although the values of democracy and participation, equality, non-discrimination and reconciliation as primary values of social development practice are not incorporated into the social work codes of ethics, they may be implied (Patel, 2005) as they can be seen as enhancing a just, equitable and democratic welfare dispensation for all people. However, Allen-Meares and Radin (2000:180) propose the on-going "need for periodic and critical re-examination" of values.

Teaching social work values by using SQ becomes even more significant when teaching and practising competently and with integrity requires that social workers should be aware of their own belief systems and values, and those of others. If this sensitivity doesn't exist, one's values and beliefs are often uncritically used as the unconscious norm for judgment; this is also called egocentricity (Paul \& Elder, 2012). Sociocentricity, on the other hand, is the belief in the inherent superiority of one's own group by judging others from the perspective of one's own group (Paul \& Elder, 2012). Social workers have to be aware of, and sensitive to, the variations of values and beliefs across cultures and contexts, and therefore question both their own and their group's values and belief systems.

Various levels of values or value systems influence the practice of social work (Drower, 1996; Haynes, 1999; Kirst-Ashman, 2010). Minimally, social work students need to be aware of the differences, similarities and interplay between professional, personal, organisational and social values, all of which incorporate ideological beliefs, with the broader society determining dominant beliefs, values and norms regarding what is 
acceptable within a particular society. Considering the interchange between these various levels of values helps students to grasp the idea that all human thoughts and actions are informed by moral beliefs - beliefs about what is good and bad, right and wrong - and how they ought to behave or act in particular situations. This, in turn, contributes to their understanding of professional ethics, which as Saleebey (2009) notes, are socially and culturally constructed. This means they are contextually or situationally determined. Hence each country has its own code of ethics which strikes a balance between the professional values of social work and the particular sociocultural norms of that country. Within the context of this background knowledge, the Socratic Questioning method can be used to help students learn how their professional values mould and shape their actions and behaviours in particular situations. Gray and Webb (2010) have highlighted how, in today's neoliberal practice environments, the appropriate practice of values is more of an accomplishment than we realise. Students need to learn the complexity of values as their personal values might differ from dominant sociocultural and political ideologies. The use of SQ can help students to negotiate their way through complex ethical conundrums and dilemmas.

\section{SOCRATIC QUESTIONING}

Socrates (c. 470-399 BC) was a Greek philosopher who believed that the best way to teach and learn was through disciplined, rigorous questioning. Often using questioning, he helped people to see either what they said they believed they did not in fact believe (as their beliefs were inconsistent with their behaviour), or that what they said they believed was conceptually sound or logical. Socrates set the agenda for the tradition of critical thinking by carefully questioning common beliefs and explanations, distinguishing those that are reasonable and logical from those which lack of a solid rational foundation. This became known as SQ, which can be described as a disciplined systematic form of questioning (Paul \& Elder, 2012). Socratic critical thinking is consequently a form of critical thinking with the focus, according to Paul and Elder (2012:438), on "fair-minded, ethical, strong-sense critical thinking."

The art of SQ is intimately connected with critical thinking, because the art of questioning is important to excellence of thought, adding systematicity, depth and an abiding interest in assessing the truth or plausibility of ideas (Paul \& Elder, 2007b). By using SQ, students get the opportunity to develop and test the ideas and beliefs they have spontaneously formed and those they have learned from caregivers and authorities in their context (Binker, 1990).

SQ, where critical thinking is used, helps students to probe their thinking to determine the extent of their knowledge on a given ethical issue and also helps them to analyse concepts or their line of reasoning concerning the profession's commitment to ethical practice. Critical thinking enables the student to question assumptions and to recognise when it is necessary to question beliefs and actions. Through teaching social work values by using SQ, students are exposed to the challenge of critical thinking, which can help them to question not only their own and societal values, but can also aid them in their own professional development in becoming critically reflective practitioners. 
Halonen (1995) claims critical thinking in social work has been overworked yet underanalysed. Critical thinking is that method of thinking about "any subject, content, or problem - in which the thinker improves the quality of his or her thinking by skilfully analysing, assessing and reconstructing it" (Paul \& Elder, 2012:xxiv). It furthermore requires open-mindedness and the ability to formulate (Mumm \& Kersting, 1997) and seek answers to ambiguous and complex problems (Coleman et al., 2002), in order to ask the next question. In social work critical thinking has been closely related to critically reflective practice and the notion of the critically reflective practitioner (Coleman et al., 2002:584). Its goal is to create a level of meta-analysis or thinking about thinking, a powerful inner voice of reason to monitor, assess and reconstitute thoughts, feelings, beliefs and actions in a rational direction (Paul \& Elder, 2007b). It implies that most things can be thought through and rational answers can be found to most questions.

Paul (1990) says SQ deeply probes the meaning, justification or logical strength of a claim, position or line of reasoning. It can be carried out in a variety of ways and adapted to many levels of ability and understanding, and is the best-known teaching strategy for critical thinking. Students should learn the discipline of SQ in order to use it in reasoning through complex matters, in understanding and assessing the thoughts of others and in following through the implications of what they and others think (Paul \& Elder, 2007c).

The aim of asking questions by using the Socratic method is to investigate the truth of a theory or opinion, elicit and develop an idea present in the mind but not yet fully developed or actualised, lead the enquiry to a logical or valid conclusion, either foreseen or unforeseen by the questioner, and elicit admission on the part of an opponent of a statement or conclusion, which can then be examined for truth or falsity (Paul \& Elder, 2007b). Accomplishing this aim implies that students have to be encouraged to explicate and dissect their beliefs and ideas as part of a worldview, that is, a comprehensive framework of beliefs about reality. It rests on the idea that in order to learn, students have to be encouraged to question their underlying beliefs with an open mind or to defend them with rational arguments. Social workers in practice have to be able to give good reasons for their decisions and actions, and need critically reflective skills to be able to understand these reasons and explain them to others, especially clients. During the process of SQ the dialogue is guided by several principles (Binker, 1990; Paul \& Elder, 2009a):

- Respond to all answers with a further question that will call upon students to develop their thinking in a fuller and deeper way;

- Seek to understand the ultimate foundations for what is said or believed and follow the implications of those foundations through further questions;

- Treat all assertions as a connecting point to further thoughts;

- Treat all thoughts as in need of development (starting with my own thoughts);

- Recognise that any thought can only fully exist in a network of connected thoughts pursue those connections; 
- Recognise that all questions presuppose prior questions and all thinking presupposes prior thinking.

When social work teachers demonstrate the above principles and students are encouraged to integrate "the ability to formulate a line of questioning, to think within new perspectives and viewpoints, and to uncover biases and distortions", they are on their way towards evolving into "strong-sense critical thinkers" (Paul \& Elder, 2012:474,475). SQ can therefore be used to help students learn how their professional values mould and shape their actions and behaviours during ethical decision-making.

\section{SOCRATIC QUESTIONING IN TEACHING PROFESSIONAL VALUES}

The Socratic method is a powerful approach to teaching and developing critical thinking skills, while the acquisition of these skills is also stressed within an African perspective (Ndofirepi, 2011). This mode of teaching implies that questioning is important to excellence of thought. Critical thinking provides the conceptual tools for understanding how the mind functions in its pursuit of meaning and truth, and SQ employs those tools in framing questions essential to this pursuit (Paul \& Elder, 2009b). Critical thinking enables us to think our way to knowledge (Paul, 2009). It stresses that "[t]thought is the key to knowledge" (Paul, 1990:xv) and that the "quality of our thinking is given in the quality of our questions" (Elder \& Paul, 2009:2). Therefore students cannot learn or come to know anything without questioning their thinking systematically, exhaustively and with breadth of vision (Elder \& Paul, 2009).

The area of values implies there is a right way of thinking and believing, and where there is a conflict - for example, between our personal and professional values - the challenge is to reason or think ourselves out of our present thinking and into a pattern of thinking that coheres with professional codes of ethics or value systems. In this learning process we need others to probe and question our ideas and values in a way that stimulates and challenges us to think deeply about them. Applying critical thinking skills can help students re-examine and change their beliefs, if necessary, to fit into their professional value system. It does this by helping students to be more rational, self-aware, honest and fair in their thoughts and actions (Paul, 2009). SQ therefore challenges students to profess and explain their underlying beliefs and values. In this way they learn how their own worldview informs the way in which they approach situations and problems. Socratic dialogue activities follow a certain procedure (Pullen-Sansfacon, 2010) of firstly asking well-formulated questions (for example: what does respect for people's worth, human rights and dignity awareness, humanity (ubuntu) and sensitivity to diversity mean within a social work context?). Below are examples of more questions that can be asked to promote critical thinking during class discussions when teaching social work values. 


\section{TABLE 1}

\section{UTILISATION OF ELEMENTS OF THOUGHT TO ASK SOCRATIC QUESTIONS}

\begin{tabular}{|l|}
\hline ELEMENTS FOR INTEL- \\
LECTUAL ENGAGEMENT \\
\hline $\begin{array}{l}\text { Recognise that all thought } \\
\text { reflects a purpose and the } \\
\text { purpose is to expose the logic of } \\
\text { thought. }\end{array}$ \\
\hline
\end{tabular}

Recognise that all thought is responsive to a question.

Recognise that no thought is fully understood until the background information (facts, data and experiences) that supports or informs it is clear. Recognise that all thought requires the making of inferences, the drawing of conclusions and the creation of meaning.

Recognise that no thought can be fully understood until one understands the concepts and ideas that define and shape it.

Recognise that all thought rests upon other thoughts, which are taken for granted or assumed.
EXAMPLES OF SOCRATIC QUESTIONS TO HELP STUDENTS BE CRITICALLY ENGAGED

What is the main purpose of personal, ideological and societal values?

What is the central purpose or goal of studying values in social work?

What kinds of questions are raised when social services are rendered to different target systems in society?

How do you implement social justice, human dignity and other social work values in addressing the social problem?

What information am I using or do I need to come to a conclusion regarding the specific social work values(s) as it applies to addressing the social issue at hand?

Is the information relevant to the issue?

Is the information evidence based?

How did I reach this conclusion?

Is there another way to interpret this specific social work value?

Should we call into question any of the inferences that were made?

What is a value? What is meant by a social work value?

What are the most basic main ideas, concepts or theories of social work and for social work?

Can I explain this idea, concept or theory on which this value is based?

What are the assumptions I am using in my thinking about social work values?

What can we safely assume as we reason through this social work value?

What assumption has led me to this conclusion?

Recognise that all thought begins somewhere (in assumptions) and goes somewhere (has implications).

Recognise that no thought can be fully understood until one understands the point of view that places it on an intellectual map.
What am I implying with this specific social work value?

What are the consequences of my stance in what I am implying with the specific social work value?

What are the consequences for the practice and implementation of social work values within a specific theory?

Which point of view am I utilising to look at social work values?

Is there another point of view I should consider?

What worldview is upheld by the client system(s)?

What is the agency's point of view?

(Adapted from Elder and Paul, 2007; Paul and Elder, 2009b) 
Secondly, examples experienced by participants have to be collected in which the given topic plays a role; one example is chosen by the students, which will usually be the basis of the analysis and reasoning throughout the discussion; crucial statements are written down on a flip chart; counter-examples are used to attempt to find inconsistencies in the discourse and finally participants strive to reach consensus (Pullen-Sansfacon, 2010).

When students are challenged to think about their values, they have to think for $a$ purpose from a particular point of view based on assumptions which, in turn, determine the decisions they make and their consequences. They use their existing knowledge, ideas and theories to interpret the situation before them and their understanding of it. In so doing they gather and assess data, facts and information in their effort to answer a question or solve a problem (Paul \& Elder, 2007d). Therefore, any discussion or any thinking about social work values guided by SQ is structured to help students to move from the obscure to the clear, from the unreasoned to the reasoned, or from the unexamined to the examined. It is a path to knowledge or knowing what to do in a particular situation. It helps students to understand the influence of their personal values on their professional behaviours and ethical decisions.

\section{IMPLICATIONS AND DISCUSSION}

Teaching social work values is not merely taking in and giving back masses of detail, as this might make students believe that they know a lot, while they lack rudimentary critical thinking skills. Didactic learning is a "product-oriented approach" (Ndofirepi, 2011:241) and dependent on memory and recall as students come up with "canned answers", because this is what is expected from them often in the name of so-called critical thinking (Paul, 1990:xvii; Paul \& Elder, 2012). Gibbons and Gray (2004:21) state that both teachers and students should be engaged in critical thinking by means of "critical talk, dialogue and engagement" about personal, societal, ideological and professional values.

Teaching social values should never be a mere flow of information from teacher to student, or a top-down "mug-and-jug" model of education, where students are filled from the teacher's jug of knowledge (Rolfe, Freshwater \& Jasper, 2001), which might eventually lead to what Thompson (2009) calls "mindless practice". The utilisation of critical thinking has practical relevance for the student, as it increases intellectual independence, increases tolerance of different points of view, and frees one from the snares of dogmatism (Murray \& Kujundzic, 2005). If a critical thinking stance is applied in which values are made explicit, social work is in a stronger position to ensure practice is consistent with those embraced values and that there is no discrepancy between what the profession claims as the ethical basis of practice and what social workers actually do in reality (Thompson, 2009).

Social work educators have the primary responsibility in modelling critical thinking and therefore it should form part of their classroom pedagogy. Teaching what critical thinking is about and how it can be applied to the content of the learning material on social work values by means of SQ becomes the point of departure for them. Teaching by means of SQ and teaching the skill of SQ can help students to question, firstly, what 
they know and understand about their own beliefs and personal values and social work values and, secondly, their own beliefs and values and social work values. They need to be helped to maintain a healthy sense of scepticism in reaction to their own values and also to professional values. According to Paul (1995), SQ will enhance students' ability to become more practised at understanding why they believe what they believe. SQ will increase students' awareness of the need to be clear, accurate and relevant in the examination of issues and discussions of these issues with others. Most importantly, they will begin to think critically in all areas of their life, examining the claims, evidence, assumptions, conclusions, implications and consequences of ideas, issues and actions.

A substantive conception of critical thinking will enable students to think within the content (Elder, 2010) of the social work values they have to learn. However, she warns against a simplistic approach to develop the mind such as a "1-2-3 step" problemsolving strategy or an approach that cannot be applied to a full range of real-life problems and issues. Students can be taught to ask relevant questions about personal, professional, ideological and societal values, for example, to clarify thinking; they can be asked to elaborate a point or exemplify it. Gibbons and Gray (2004) recommend that teachers need to encourage students to unearth and challenge assumptions, while theories and approaches should be analysed and questioned. To foster reasonability in thought, they can be asked whether there is a more logical interpretation of the data; encouraging fairness requires them to ask whether they have considered all relevant viewpoints in good faith (Elder, 2010). According to Coleman et al. (2002), skills in critical thinking are essential for social workers, as clients need to be assured that service delivery is based on the best evidence, knowledge and practices in a given situation. Paul and Elder (2012:475) go so far as to state that strong-sense critical thinkers "strive always to be ethical", because they have the ability and propensity to change their thinking when the evidence would require it.

The quality of our lives and that of what we produce, make or build depends on the quality of our thought. Thinking is a complex phenomenon, routinely highlighted, discussed and critiqued in every relationship, in every family, in every business and organisation, in every field and discipline, and in every part of culture (Elder \& Cosgrove, 2009). Critical thinkers understand the value of taking their thinking apart (Paul \& Elder, 2012). The necessity for critical thinking becomes even more apparent as social workers are often the embodiment of sound reasoning in the lives of clients.

Social work education should enable the student to be skilled in breaking down reading, writing, speaking, reasoning and listening regarding social work values using the elements of critical thinking. Teaching social work values by means of SQ helps the student to move through the process of critical thinking development - moving from being an unreflective thinker to becoming an accomplished thinker, where intellectual skills and virtues have become second nature in their lives. If we want a critical society in social work, fostering critical thinking concerning social work values may be a good starting point. 
Embracing the cultivation of critical thinking in students has to be followed up by tying assessment to critical thinking (Paul, 2009) about social work values. The following questions can guide the educator: How do I assess students' learning to think their way through their personal, societal, ideological and professional values? How do I assess the extent to which they are learning to reason within different cultural groups' values and viewpoints? Designing and conducting Socratic discussions in class using the concepts and principles of critical thinking is a starting point in the continuous assessment of students in social work.

Social work is a value-laden profession which is articulated in codes of practice, codes of conduct, and codes of ethics, which variously assist and guide social workers' practice. Congress (2006) states that the most effective way of teaching ethics and human rights in social work implies integrating ethics content into all courses, as well as presenting separate ethics courses. She underlines the necessity of including national codes of ethics, as well as international codes on ethics and human rights in the curriculum. Critical thinking as an outcome should therefore form part of every exitlevel outcome in social work training, from BSW to doctoral level. Elder (2010) is of the opinion that faculty members often mistakenly assume that they need only a few handy critical thinking strategies to boost their teaching. Becoming effective educators in teaching social work values means to work your way methodically through the theory of critical thinking and apply it not only in class but also in life.

\section{CONCLUSION}

Coming from different backgrounds with different worldviews, social work students should be urged by educators to be aware of, and sensitive to, the ways in which their value preferences continuously influence and pervade the process of acquiring professional values. Mere verbal recalling and agreement on professional values alone will not necessarily enable the social work student to accomplish a reflective stance on the influence of personal, societal and ideological values on professional values. Acquiring and mastering of social work values during education and training require a form of professional socialisation where the mastering of critical thinking is an important point of departure in grasping these values.

The utilisation of SQ in framing questions in teaching professional values helps students to become aware of own belief systems underlying their personal, ideological and societal values and the influence of these on social work values. Reflecting on students' underlying beliefs is an integrative process driven by critical thinking, as it enables students to develop as independent thinkers concerned with mindful and ethical practice. Critical thinking in fostering professional values for ethical decision-making is the cornerstone of sound practice.

In order to make this practicable in teaching, firstly, educators in social work should get training themselves on what critical thinking and the art of SQ is; secondly, teach students the underlying principles of critical thinking and the art of SQ; and thirdly, make sure that course outcomes are formulated to mirror critical thinking as part of the social work students' training in professional values. Lastly, educators should ensure 
that teaching takes place in accordance with these outcomes. The utilisation of SQ therefore supports the social work value of integrity, namely being aware of one's own belief systems and values as an important point of departure for acquiring social work values. Acquiring these values is essential, as it forms the basis on which the eventual ethical decision-making for professional action rests when interacting with client systems within a diverse society.

Social work educators have the responsibility to help social work students understand and espouse the values of the profession, not merely by having them recite the values of social work, but also to enable them to discuss, review, debate and eventually practise within an ever-changing context. Integrity as a social work value requires that the social workers should be aware of their own belief systems and values and their effect on service rendering. One way of doing this is by means of SQ.

\section{REFERENCES}

ABBOTT, A.A. 2003. A confirmatory analysis of the professional opinion scale: a values assessment instrument. Research on Social Work Practice, 13(5):641-666.

ALLEN-MEARES, P. \& RADIN, N. 2000. Our professional values and the changing environment. Social Work Education, 36(2):179-182.

BINKER, A.J.A. 1990. Socratic questioning. In: PAUL, R. \& BINKER, A.J.A. (ed) Critical thinking - what every person needs to survive in a rapidly changing world. Rohnert Park, CA: Sonoma State University, Center for Critical Thinking and Moral Critique, 269-298.

BONNYCASTLE, C.R. 2011. Social justice along a continuum: a relational illustrative model. Social Service Review, 85(2):266-295.

COLEMAN, H., ROGERS, G. \& KING, J. 2002. Using portfolios to stimulate critical thinking in social work education. Social Work Education, 21(5):583-595.

CONGRESS, E.P. 2006. Teaching social work values, ethics and human rights. In: Social work: making a world of difference: Social Work around the World IV. Berne, Switzerland: International Federation of Social Workers (IFSW), 1-16.

DROWER, S.J. 1996. Social work values, professional unity, and the South African context. Social Work, 41(2):138-146.

ELDER, L. 2010. Achieving critical mass. Times Higher Education. [Online] Available: http://www.timeshighereducation.co.uk/story.asp?sectioncode=26\&storycode $=41435$ [Accessed: 01/04/2011].

ELDER, L. \& COSGROVE, R. 2009. Critical societies- thoughts from the past: critical thinking, the educated mind, and the creation of critical societies. Dillon Beach, CA: Foundation for Critical Thinking.

ELDER, L. \& PAUL, R. 2007. The miniature guide to taking charge of the human mind. Thinking, feeling, wanting. Based on critical thinking concepts and principles. Dillon Beach, CA: Foundation for Critical Thinking Press. 
ELDER, L. \& PAUL, R. 2009. The art of asking essential questions ( ${ }^{\text {th }}$ ed). Dillon Beach, CA: Foundation for Critical Thinking Press.

GIBBONS, J. \& GRAY, M. 2004. Critical thinking as integral to social work practice. Journal of Teaching in Social Work, 24(1/2):19-38.

GOVERNMENT GAZETTE NO. 18787 of 28 March. 1998. Regulations under the South African Qualifications Authority Act, 1995. Schedule. Pretoria: Government Printer.

GOVERNMENT GAZETTE NO. 30353 of 5 October. 2007. Higher Education Act 101 of 1997. The Higher Education Qualifications Framework. Pretoria: Government Printer.

GRAHAM, M.J. 1999. The African-centred worldview: developing a paradigm for social work. British Journal for Social Work, 29(2):251-267.

GRAY, M. \& GIBBONS, J. 2007. There are no such answers, only choices: teaching ethical decision making in Social Work. Australian Social Work, 60(2):222-238.

GRAY, M. \& STOFBERG, J.A. 2000. Social work and respect for persons. Australian Journal of Social Work, 53(3):55-61.

GRAY, M. \& WEBB, S.A. 2010. Introduction: ethics and value perspectives in social work. In: GRAY, M. \& WEBB, S.A. (eds) Ethics and value perspectives in social work. Basingstoke: Palgrave, 1-18.

HALONEN, J. 1995. Demystifying critical thinking. Teaching of Psychology, 22(1):75-81.

HAYNES, D.T. 1999. A theoretical integrative framework for teaching professional social work values. Journal of Social Work Education, 35(1):39-50.

HEPWORTH, D.H., ROONEY, R.H., ROONEY, G.D., STROM-GOTTFRIED, K. \& LARSEN, J. 2002. Direct social work practice - theory and skills $\left(6^{\text {th }}\right.$ ed). Pacific Grove, CA: Brooks/Cole.

IFSW (International Federation of Social Work). 2000. Definition of Social Work. [Online] Available: www.ifsw.org/f38000138.html? [Accessed: 11/04/2011].

KIRST-ASHMAN, K.K. 2010. Introduction to social work and social welfare critical thinking perspectives $\left(3^{\text {rd }} \mathrm{ed}\right)$. Belmont, $\mathrm{CA}$ : Brooks/Cole.

MUMM, A.M. \& KERSTING, R.C. 1997. Teaching critical thinking in social work practice. Journal of Social Work Education, (1):75-84.

MURRAY, M. \& KUJUNDZIC, N. 2005. Critical reflection: a textbook for critical thinking. Montreal and Kingston, London: McGill-Queen's University Press.

NDOFIREPI, A.P. 2011. Philosophy for children: the quest for an African perspective. South African Journal of Education, 31(2):246-256.

PAJARES, M.F. 1992. Teachers' beliefs and educational research: cleaning up a messy construct. Review of Educational Research, 62(3):307-333. 
PATEL, L. 2005. Social development practice model. In: PATEL, L. (ed) Social welfare and social development in South Africa. Cape Town, South Africa: Oxford University Press Southern Africa, 202-233.

PATEL, L., TRIEGAARDT, J. \& NDANGWA, N. 2005. Developmental social welfare services. In: PATEL, L. (ed) Social welfare and social development in South Africa. Cape Town, South Africa: Oxford University Press Southern Africa, 154-200.

PAUL, R. 1990. Introduction. In: PAUL, R. \& BINKER, A.J.A. (ed) Critical thinking: what every person needs to survive in a rapidly changing world. Rohnert Park, CA: Sonoma State University, Center for Critical and Morale Critique, xv-xx.

PAUL, R. 1995. Critical thinking: how to prepare students for a rapidly changing world. Santa Rosa, CA: Foundation for Critical Thinking.

PAUL, R. 2009. Critical thinking: where to begin. Santa Rosa, CA: Foundation for Critical Thinking.

PAUL, R. \& ELDER, L. 2007a. A guide for educators to critical thinking competency standards: standards, principles, performance indicators and outcomes with a critical thinking master rubric. Dillon Beach, CA: The Foundation for Critical Thinking.

PAUL, R. \& ELDER, L. 2007b. The art of Socratic questioning: based on critical thinking concepts and tools. Dillon Beach, CA: The Foundation for Critical Thinking.

PAUL, R. \& ELDER, L. 2007c. Educational fads: how to get beyond educational glitz and glitter. Dillon Beach, CA: The Foundation for Critical Thinking.

PAUL, R. \& ELDER, L. 2007d. The thinker's guide for students on how to study and learn a discipline using critical thinking concepts and tools. Dillon Beach, CA: The Foundation for Critical Thinking.

PAUL, R. \& ELDER, L. 2009a. The role of Socratic questioning in thinking, teaching and learning. Dillon Beach, CA: Foundation for Critical Thinking. [Online] Available: $\quad$ http://www.criticalthinking.org/page.cfm?PageID=522\&CategoryID=71 [Accessed: 30/11/2010].

PAUL, R. \& ELDER, L. 2009b. Understanding the foundation of ethical reasoning. Based on critical thinking concepts and tools. Dillon Beach, CA: The Foundation of Critical Thinking.

PAUL, R. \& ELDER, L. 2012. Critical thinking - tools for taking charge of your learning and your life $\left(3^{\text {rd }}\right.$ ed). Boston, MA: Pearson.

PAYNE, M. 2006. What is professional social work? ( $2^{\text {nd }}$ ed). Bristol: Policy Press. PAYNE, H. \& LITTLECHILD, B. 2000. Ethical practice and the abuse of power in social responsibility. London: Jessica Kingsley.

PERLMAN, H.H. 1976. Believing and doing: values in social work education. Social Casework, 57(6):381-390. 
PINKERTON, J. 2002. Child protection. In: ADAMS, R., DOMINELLI, L. \& PAYNE, M. (eds) Critical practice in social work. Basington, Hampshire: Palgrave MacMillan, 96-105.

PULLEN-SANSFACON, A. 2010. Virtue ethics for social work: a new pedagogy for practical reasoning. Social Work Education, 29(4):402-415.

ROLFE, G., FRESHWATER, D. \& JASPER, M. 2001. Critical reflection for nursing and the helping professions. Basingstoke, Hampshire: Palgrave MacMillan.

SALEEBEY, D. 2009. The strengths perspective in social work practice $\left(5^{\text {th }} \mathrm{ed}\right)$. Boston, MA: Pearson Education.

SACSSP (South African Council of Social Service Professions). 2004. Policy Guidelines for Course of Conduct, Code of Ethics and the Rules for Social Worker. [Online] Available: www.sacssp.co.za/UserFiles/File/SACSSP\%20Code\%20Ethics.pdf [Accessed: 22/11/2010].

SAQA (South African Qualifications Authority). 2009. Registered Qualification: BSW NQF level 08. [Online] Available: http://regqs.saqa.org.za/viewQualification. php?id= 23994; http://regqs.saqa.org.za/viewQualification.php?id=58582

[Accessed: 15/02/2014].

SAQA (South African Qualifications Authority). 2010. Level Descriptors for the South African National Qualifications Framework. [Online] Available: http://regqs. saqa.org.za/viewQualification.php?id=23994 [Accessed: 02/08/2014].

SHARDLOW, S.M. 2009. Values, ethics and social work. In: ADAMS, R., DOMINELLI, L. \& PAYNE, M. (eds) Social work themes, issues and critical debates $\left(3^{\text {rd }}\right.$ ed). Basingstoke, Hampshire: Palgrave MacMillan, 37-48.

SOUTH AFRICA. 1978. Social Service Professions Act 110 of 1978. Pretoria: Government Printer.

THOMPSON, N. 2009. Practising social work: meeting the professional challenge. Basingstoke, Hampshire: Palgrave MacMillan.

WALSH, T. 2010. The solution-focused helper: ethics and practice in health and social care. New York, NY: McGraw-Hill Open University Press.

Dr Sandra Berna Ferreira, Department of Social Work, University of the Free State, Bloemfontein, South Africa; Dr Regardt Jacobus Ferreira., Tulane School of Social Work, Tulane University, New Orleans, United States of America. 